\title{
Originals
}

\section{Somatostatin Infusion in Liver Cirrhosis: Glucagon Control of Glucose Homeostasis}

\author{
A. V. Greco, L. Altomonte, G. Ghirlanda, A. G. Rebuzzi, R. Manna, and A. Bertoli \\ Istituto di Patologia Medica, Catholic University, Rome, Italy
}

\begin{abstract}
Summary. In order to evaluate the role of glucagon in blood glucose homeostasis in liver cirrhosis, ten normal subjects and ten cirrhotic patients were infused with somatostatin $(500 \mu \mathrm{g} / \mathrm{h}$ for $5 \mathrm{~h})$ with and without glucagon $(3 \mathrm{mg} / \mathrm{kg} / \mathrm{h})$ administration. Somatostatin infusion brought about a fall in plasma glucose both in normal $(37 \%)$ and cirrhotic $(41 \%)$ subjects in the first 90 minutes. In normal subjects, this was followed by a rise in plasma glucose $(147 \pm 2 \mathrm{mg} / \mathrm{dl}$ at $5 \mathrm{~h}$ ), while in cirrhotics no rise in plasma glucose was observed $(50 \pm 1 \mathrm{mg} / \mathrm{dl}$ at $5 \mathrm{~h})$. Plasma insulin and glucagon levels were suppressed in both normal and cirrhotic subjects. Addition of glucagon to the somatostatin infusion caused a two fold rise in plasma glucose level to $183 \pm 12 \mathrm{mg} / \mathrm{dl}$ at $4 \mathrm{~h}$ in normal subjects; a much smaller increase was found in the cirrhotic group $(105 \pm 3 \mathrm{mg} / \mathrm{dl}$ at $4 \mathrm{~h})$. When the infusion was stopped, plasma glucose fell both in normal and cirrhotic subjects (102 \pm 14 and $87 \pm 2$ $\mathrm{mg} / \mathrm{dl}$ at $6 \mathrm{~h}$ respectively). Subsequently, hyperglucagonaemia recurred in the cirrhotic patients (319 $\pm 31 \mathrm{pg} / \mathrm{ml})$. A rebound of plasma insulin was observed in normal subjects $(47 \pm 8 \mu \mathrm{U} / \mathrm{ml})$ which did not occur in the cirrhotics $(16 \pm 2 \mu \mathrm{U} / \mathrm{ml})$. Thus when both insulin and glucagon were suppressed by somatostatin infusion, euglycaemia occurred in cirrhotic subjects only when glucagon concentration was restored exogenously. We conclude that glucagon is important in glucose homeostasis in patients with liver cirrhosis.
\end{abstract}

Key words: Cirrhosis, somatostatin, glucagon, plasma glucose, glucose intolerance, insulin.

The hypothesis that pancreatic glucagon plays an important role in glucose homeostasis has been supported by studies with infusion of somatostatin $[2,7$,
$9,15,25]$, a powerful inhibitor of both insulin and glucagon secretion $[1,2,13,17]$.

Hyperglucagonaemia is known to be present in liver cirrhosis $[11,16,18,20,22]$; the effect and importance of this with respect to metabolic regulation is as yet not fully understood.

The present investigation was undertaken in order to evaluate the contribution of glucagon to glucose homeostasis in cirrhotic patients by studying plasma glucose changes during prolonged somatostatin infusion with and without administration of glucagon.

\section{Material and Methods}

Two groups of subjects were studied, a control group of ten healthy male volunteers aged $28-36$, whose body weights were within 15 per cent of the ideal value (Metropolitan Life Insurance Tables, 1959) and a group of ten male non diabetic, non ascitic cirrhotic patients aged 39-49 whose body weights, ranging from 53 to $68 \mathrm{~kg}$ (average $60 \pm 7 \mathrm{~kg}$ ), $96 \pm 2 \%$ of ideal body weight. The diagnosis of liver cirrhosis was confirmed by peritoneoscopy and liver biopsy in every case. Characteristics of cirrhotic subjects at selection are shown in Table 1.

All subjects were informed of the nature, purpose and possible risks of the study and had given their consent to participate.

For at least one week before the test, the subjects were fed a daily diet of about 3000 Calories with at least $280 \mathrm{~g}$ of carbohydrate. All tests were performed after an overnight fast. Catheters were introduced into the antecubital veins of both arms, one for drawing blood and the other for the infusion of somatostatin, saline $(0.154 \mathrm{~mol} / \mathrm{l})$ or glucagon. After baseline blood specimens had been obtained over a $60 \mathrm{~min}$ period $250 \mu \mathrm{g}$ of sterile synthetic pyrogen-free cyclic somatostatin was injected; somatostatin infusion was then continued at on hourly rate of $500 \mu \mathrm{g}$ for $5 \mathrm{~h}$. In addition, from the second to the fourth hour, all subjects were infused with saline $(0.154 \mathrm{~mol} / \mathrm{l})$ or glucagon $(3 \mathrm{ng} / \mathrm{kg} / \mathrm{min})$ which yielded plasma glucagon levels of approximately $300-350 \mathrm{pg} / \mathrm{ml}$. Blood specimens were drawn at 15-min intervals for the following $5 \mathrm{~h}$. Heparinized blood specimens for insulin assay were centrifuged at $4{ }^{\circ} \mathrm{C}$ and subsequently frozen at $-20^{\circ} \mathrm{C}$ until assay; for glucagon assay, $4 \mathrm{ml}$ of blood were placed into chilled tubes containing $0.2 \mathrm{ml}$ of disodium edetate solution $(1.2 \mathrm{mg} / \mathrm{ml}$ blood); 
Table 1. Laboratory values at selection in cirrhotic subjects. Normal ranges established for a large group of physicians, laboratory personell and nurses, none with any known disease

\begin{tabular}{|c|c|c|c|c|c|c|c|c|}
\hline $\begin{array}{l}\text { Alcoholic } \\
\text { cirrhosis }\end{array}$ & $\begin{array}{l}\text { Oesophageal } \\
\text { varices }\end{array}$ & $\begin{array}{l}\text { Bilirubin } \\
(\mu \mathrm{mol} / \mathrm{l})\end{array}$ & $\begin{array}{l}\text { Aspartate } \\
\text { transaminase } \\
\text { I. U./ } 1\end{array}$ & $\begin{array}{l}\text { Albumin } \\
\mathrm{g} / 1\end{array}$ & $\begin{array}{l}\text { Prothrombin } \\
\text { time } \%\end{array}$ & $\begin{array}{l}\text { Fasting plasma } \\
\text { glucose } \\
\mathrm{mg} / \mathrm{dl}\end{array}$ & $\begin{array}{l}\text { Fasting } \\
\text { insulin } \\
\text { (IRI) } \mu \mathrm{U} / \mathrm{ml}\end{array}$ & $\begin{array}{l}\text { Fasting } \\
\text { glucagon } \\
\text { (IRG) pg/ml }\end{array}$ \\
\hline 1 & + & 26 & 36 & 16 & 56 & 91 & 20 & 323 \\
\hline 2 & + & 52 & 20 & 32 & 62 & 92 & 18 & 254 \\
\hline 3 & + & 38 & 54 & 40 & 58 & 101 & 16 & 264 \\
\hline 4 & - & 46 & 51 & 29 & 70 & 86 & 8 & 198 \\
\hline 5 & + & 16 & 26 & 18 & 65 & 89 & 34 & 340 \\
\hline 6 & + & 57 & 64 & 20 & 50 & 94 & 12 & 126 \\
\hline 7 & + & 24 & 38 & 22 & 58 & 87 & 44 & 364 \\
\hline 8 & + & 63 & 70 & 36 & 78 & 88 & 21 & 304 \\
\hline 9 & - & 38 & 66 & 32 & 70 & 93 & 20 & 258 \\
\hline 10 & - & 44 & 50 & 24 & 58 & 78 & 24 & 228 \\
\hline \multicolumn{2}{|c|}{ Mean $\pm S E M$} & $40 \pm 5$ & $48 \pm 5$ & $27 \pm 3$ & $63 \pm 3$ & $90 \pm 2$ & $22 \pm 3$ & $266 \pm 23$ \\
\hline \multicolumn{2}{|c|}{ Normal range } & $5-17$ & $5-15$ & $35-50$ & $90-100$ & $80-100$ & $8-16$ & $70-130$ \\
\hline
\end{tabular}

after centrifugation, the plasma was separated and frozen until assay. Plasma glucose was determined by the glucose oxidase method in a Beckman analyzer; plasma insulin (IRI) was estimated radioimmunologically [12]; glucagon was measured radioimmunologically with Unger's $30 \mathrm{~K}$ antiserum [24].

Results are presented as means \pm SEM. Student's $t$ test for unpaired data was employed for statistical analysis.

\section{Results}

Figure 1 shows the results obtained with somatostatin and glucagon infusion in normal and cirrhotic subjects.

Fasting plasma glucose levels were similar in both groups (Table 2). In normal subjects after 90 minutes of somatostatin infusion plasma glucose had fallen by $37 \%$ to $55 \pm 3 \mathrm{mg} / \mathrm{dl}$; the level then rose again reaching $147 \pm 2 \mathrm{mg} / \mathrm{dl}$ at 5 hours. When somatostatin was stopped, plasma glucose returned to normal.

Cirrhotic subjects showed a similar fall in plasma glucose during the first 90 minutes $(50 \pm 3 \mathrm{mg} / \mathrm{dl})$ but thereafter plasma glucose levels remained low, values differing significantly from those observed in normal subjects (Table 2). Once the infusion was stopped, plasma glucose concentration returned to normal.

Basal plasma insulin values (Table 3 ) did not differ significantly between normal and cirrhotic subjects; during somatostatin infusion, insulin levels were markedly suppressed. Basal plasma glucagon values (Table 4) were significantly higher in cirrhotic patients as compared to normal controls ( $351 \pm 15$ as against $99 \pm 2 \mathrm{pg} / \mathrm{ml} ; \mathrm{P}<0.001)$. After somatostatin infusion, glucagon levels were markedly suppressed and the difference between the two groups disappeared.

IV glucagon infusion ( $3 \mathrm{ng} / \mathrm{kg} / \mathrm{min}) 2$ hours after the beginning of somatostatin infusion brought the glucagon levels to $293 \pm 11 \mathrm{pg} / \mathrm{ml}$ in normals and $368 \pm 6 \mathrm{pg} / \mathrm{ml}$ in cirrhotics respectively within 90 minutes. At the same time, a gradual rise in plasma glucose was observed which after 120 minutes of glucagon infusion reached $183 \pm 12 \mathrm{mg} / \mathrm{dl}$ in normals and $105 \pm 3 \mathrm{mg} / \mathrm{dl}$ in cirrhotics $(\mathrm{P}<0.001)$. When glucagon was stopped, plasma glucose values in cirrhotics dropped to a level significantly lower than that of normal subjects ( $83 \pm 2$ compared to $146 \pm 15 \mathrm{mg} / \mathrm{dl} ; \mathrm{P}<0.001)$.

After somatostatin infusion was stopped, a fall in plasma glucose was observed $(120 \pm 14 \mathrm{mg} / \mathrm{dl})$; in the cirrhotic patients, basal plasma glucose values were reached in about an hour $(87 \pm 2 \mathrm{mg} / \mathrm{dl})$. Plasma glucagon returned to basal values rapidly both in normals and cirrhotics; this, in the latter led again to a condition of hyperglucagonaemia (320 \pm $32 \mathrm{pg} / \mathrm{ml})$. In normal subjects, an insulin rebound was observed at 6 hours $(47 \pm 8 \mu \mathrm{U} / \mathrm{ml})$ contrary to what was found in cirrhosis $(16 \pm 2 \mu \mathrm{U} / \mathrm{ml})$.

\section{Discussion}

The group of control subjects had a different mean age than the cirrhotics but that did not seem to influence our results significantly. Berger et al. [4] stated that plasma insulin levels did not change appreciably with age. Plasma glucagon levels change slightly from 20 to 40 years of age and glucose shows variations of $1-2 \mathrm{mg} / \mathrm{dl}$ per decade.

It has been clearly established that glucagon plays a physiological role in maintaining fasting euglycaemia in man $[2,5,6,9,14,15,23]$. Somatostatin infusion initially lowers basal plasma glucose in nor$\mathrm{mal}$ and diabetic man and it is suggested that this hypoglycaemic effect is a consequence of glucagon suppression $[8-10,17]$. This fall is a reflection of 
Table 2. Plasma glucose levels $(\mathrm{mg} / \mathrm{dl})$ before and after infusion with somatostatin (SRIF) $(500 \mu \mathrm{g} / \mathrm{h})+-$ saline or glucagon $(3 \mathrm{ng} / \mathrm{kg} / \mathrm{min})$ in normal and cirrhotic subjects. Values are mean \pm SEM

Statistical significance $(\mathrm{P}<0.01)$ between ${ }^{\mathrm{a}} \mathrm{A}$ and $\mathrm{B} ;{ }^{\mathrm{b}} \mathrm{A}$ and $\mathrm{C} ;{ }^{\mathrm{c}} \mathrm{A}$ and $\mathrm{D} ;{ }^{d} \mathrm{~B}$ and $\mathrm{C} ;{ }^{\mathrm{e}} \mathrm{B}$ and $\mathrm{D} ;{ }^{\mathrm{f}} \mathrm{C}$ and $\mathrm{D}$

\begin{tabular}{|c|c|c|c|c|c|c|c|c|c|c|c|c|c|c|c|c|}
\hline Minutes & -30 & 0 & 15 & 30 & 45 & 60 & 90 & 120 & 150 & 180 & 210 & 240 & 270 & 300 & 330 & 360 \\
\hline $\begin{array}{l}\text { Normals } \\
\text { (SRIF + } \\
\text { saline) } \\
\text { A. }\end{array}$ & $\begin{array}{l}87 \\
\pm 3\end{array}$ & $\begin{array}{l}86 \\
\pm 3\end{array}$ & $\begin{array}{l}81 \\
\pm 4\end{array}$ & $\begin{array}{l}72 \\
\pm 4\end{array}$ & $\begin{array}{l}64 \\
\pm 3\end{array}$ & $\begin{array}{l}60 \\
\pm 3\end{array}$ & $\begin{array}{l}55 \\
\pm 3\end{array}$ & $\begin{array}{r}65 \\
\pm 4\end{array}$ & $\begin{array}{c}78 \\
\pm 2\end{array}$ & $\begin{array}{r}89 \\
\pm 2\end{array}$ & $\begin{array}{l}108 \\
\pm 4\end{array}$ & $\begin{array}{l}117 \\
\pm 7\end{array}$ & $\begin{array}{l}125 \\
\pm 4\end{array}$ & $\begin{array}{l}147 \\
\pm 2\end{array}$ & $\begin{array}{l}153 \\
\pm 2\end{array}$ & $\begin{array}{l}127 \\
\pm 4\end{array}$ \\
\hline $\begin{array}{l}\text { Normals } \\
\text { (SRIF + } \\
\text { glucagon) } \\
\text { B. }\end{array}$ & $\begin{array}{l}87 \\
\pm 6\end{array}$ & $\begin{array}{l}83 \\
\pm 6\end{array}$ & $\begin{array}{l}78 \\
\pm 5\end{array}$ & $\begin{array}{l}70 \\
\pm 6\end{array}$ & $\begin{array}{l}64 \\
\pm 4\end{array}$ & $\begin{array}{l}60 \\
\pm 4\end{array}$ & $\begin{array}{l}55 \\
\pm 3\end{array}$ & $\begin{array}{c}67 \\
\pm 7\end{array}$ & $\begin{array}{c}90 \\
\pm 12\end{array}$ & $\begin{array}{l}151^{\mathrm{a}} \\
\pm 16\end{array}$ & $\begin{array}{l}167^{\mathrm{a}} \\
\pm 13\end{array}$ & $\begin{array}{l}183^{\mathrm{a}} \\
\pm 12\end{array}$ & $\begin{array}{l}159 \\
\pm 13\end{array}$ & $\begin{array}{l}146 \\
\pm 15\end{array}$ & $\begin{array}{l}120 \\
\pm 14\end{array}$ & $\begin{array}{l}102 \\
\pm 14\end{array}$ \\
\hline $\begin{array}{l}\text { Cirrhotics } \\
\text { (SRIF + } \\
\text { saline) } \\
\text { C. }\end{array}$ & $\begin{array}{l}84 \\
\pm 3\end{array}$ & $\begin{array}{l}86 \\
\pm 2\end{array}$ & $\begin{array}{l}80 \\
\pm 4\end{array}$ & $\begin{array}{l}79 \\
\pm 2\end{array}$ & $\begin{array}{l}62 \\
\pm 1\end{array}$ & $\begin{array}{l}53 \\
\pm 2\end{array}$ & $\begin{array}{l}50 \\
\pm 3\end{array}$ & $\begin{array}{c}50 \\
\pm 3\end{array}$ & $\begin{array}{c}49 \\
\pm 1\end{array}$ & $\begin{array}{c}51^{\mathrm{b}, \mathrm{d}} \\
\pm 1.5\end{array}$ & $\begin{array}{l}51^{\mathrm{b}, \mathrm{d}} \\
\pm 2\end{array}$ & $\begin{array}{l}52^{\mathrm{b}, \mathrm{d}} \\
\pm 3\end{array}$ & $\begin{array}{l}51^{\mathrm{b}, \mathrm{d}} \\
\pm 2\end{array}$ & $\begin{array}{l}50^{\mathrm{b}, \mathrm{d}} \\
\pm 1\end{array}$ & $\begin{array}{c}81^{\mathrm{b}, \mathrm{d}} \\
\pm 3.5\end{array}$ & 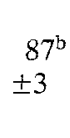 \\
\hline $\begin{array}{l}\text { Cirrhotics } \\
\text { (SRIF + } \\
\text { glucagon) } \\
\text { D. }\end{array}$ & $\begin{array}{l}85 \\
\pm 4\end{array}$ & $\begin{array}{l}89 \\
\pm 2\end{array}$ & $\begin{array}{l}81 \\
\pm 4\end{array}$ & $\begin{array}{l}79 \\
\pm 1\end{array}$ & $\begin{array}{l}66 \\
\pm 3\end{array}$ & $\begin{array}{l}56 \\
\pm 1\end{array}$ & $\begin{array}{l}55 \\
\pm 3\end{array}$ & $\begin{array}{c}50^{c} \\
\pm 0.2\end{array}$ & $\begin{array}{c}96^{\mathrm{c}, \mathrm{f}} \\
\pm 2\end{array}$ & $\begin{array}{l}100^{c, e, f} \\
\pm 3\end{array}$ & $\begin{array}{l}102^{\mathrm{e}, \mathrm{f}} \\
\pm 4\end{array}$ & $\begin{array}{l}106^{e, f} \\
\pm 3\end{array}$ & $\begin{array}{l}95^{\mathrm{c}, \mathrm{e}, \mathrm{f}} \\
\pm 4\end{array}$ & $\begin{aligned} & 83^{\mathrm{c}, \mathrm{e}, \mathrm{f}} \\
\pm & 2\end{aligned}$ & $\begin{array}{l}112^{\mathrm{c}, \mathrm{e}} \\
\pm 3\end{array}$ & $\begin{array}{c}87^{\mathrm{c}} \\
\pm 2\end{array}$ \\
\hline
\end{tabular}

Table 3. Plasma insulin levels $(\mu \mathrm{U} / \mathrm{ml})$ before and after infusion with somatostatin (SRIF) $(500 \mu \mathrm{g} / \mathrm{h})+\mathrm{saline}$ or glucagon $(3 \mathrm{ng} / \mathrm{kg} / \mathrm{min})$ in normal and cirrhotic subjects. Values are mean \pm SEM

Statistical significance $(\mathrm{P}<0.01)$ between ${ }^{\mathrm{a}} \mathrm{A}$ and $\mathrm{C} ;{ }^{\mathrm{b}} \mathrm{A}$ and $\mathrm{D} ;{ }^{\mathrm{c}} \mathrm{B}$ and $\mathrm{C} ;{ }^{\mathrm{d}} \mathrm{B}$ and $\mathrm{D}$

\begin{tabular}{|c|c|c|c|c|c|c|c|c|c|c|c|c|c|c|c|c|}
\hline Minutes & -30 & 0 & 15 & 30 & 45 & 60 & 90 & 120 & 150 & 180 & 210 & 240 & 270 & 300 & 330 & 360 \\
\hline $\begin{array}{l}\text { Normals } \\
\text { (SRIF + } \\
\text { saline) } \\
\text { A. }\end{array}$ & $\begin{array}{l}17 \\
\pm 1\end{array}$ & $\begin{array}{l}16 \\
\pm 1\end{array}$ & $\begin{array}{c}7 \\
\pm 0.5\end{array}$ & $\begin{array}{c}5 \\
\pm 1\end{array}$ & $\begin{array}{c}4 \\
\pm 0.3\end{array}$ & $\begin{array}{c}5 \\
\pm 0.5\end{array}$ & $\begin{array}{c}4 \\
\pm 0.8\end{array}$ & $\begin{array}{c}4 \\
\pm 0.9\end{array}$ & $\begin{array}{c}6 \\
\pm 0.7\end{array}$ & $\begin{array}{c}5 \\
\pm 0.2\end{array}$ & $\begin{array}{c}5 \\
\pm 0.8\end{array}$ & $\begin{array}{c}5 \\
\pm 0.8\end{array}$ & $\begin{array}{r}3.5 \\
\pm 0.4\end{array}$ & $\begin{array}{c}4 \\
\pm 0.3\end{array}$ & $\begin{array}{c}47 \\
\pm 5\end{array}$ & $\begin{array}{c}47 \\
\pm 9\end{array}$ \\
\hline $\begin{array}{l}\text { Normals } \\
\text { (SRIF + } \\
\text { glucagon) } \\
\text { B. }\end{array}$ & $\begin{array}{l}14 \\
\pm 1\end{array}$ & $\begin{array}{l}15 \\
\pm 1\end{array}$ & $\begin{array}{c}9 \\
\pm 0.6\end{array}$ & $\begin{array}{c}6 \\
\pm 1\end{array}$ & $\begin{array}{c}4 \\
\pm 0.5\end{array}$ & $\begin{array}{c}3 \\
\pm 0.3\end{array}$ & $\begin{array}{c}3 \\
\pm 0.4\end{array}$ & $\begin{array}{c}4 \\
\pm 0.6\end{array}$ & $\begin{array}{c}5 \\
\pm 0.6\end{array}$ & $\begin{array}{c}3 \\
\pm 0.2\end{array}$ & $\begin{array}{c}5 \\
\pm 0.8\end{array}$ & $\begin{array}{c}5 \\
\pm 0.8\end{array}$ & $\begin{array}{c}3 \\
\pm 0.4\end{array}$ & $\begin{array}{c}4 \\
\pm 0.2\end{array}$ & $\begin{array}{c}48 \\
\pm 5\end{array}$ & $\begin{array}{c}30 \\
\pm 5\end{array}$ \\
\hline $\begin{array}{l}\text { Cirrhotics } \\
\text { (SRIF + } \\
\text { saline) } \\
\text { C. }\end{array}$ & $\begin{array}{l}20 \\
\pm 1\end{array}$ & $\begin{array}{l}22 \\
\pm 2\end{array}$ & $\begin{array}{l}10 \\
\pm 1\end{array}$ & $\begin{array}{c}7 \\
\pm 0.5\end{array}$ & $\begin{array}{c}4 \\
\pm 1\end{array}$ & $\begin{array}{c}4 \\
\pm 0.3\end{array}$ & $\begin{array}{c}5 \\
\pm 1\end{array}$ & $\begin{array}{c}4 \\
\pm 1\end{array}$ & $\begin{array}{c}3 \\
\pm 0.7\end{array}$ & $\begin{array}{c}4 \\
\pm 0.3\end{array}$ & $\begin{array}{c}4 \\
\pm 0.4\end{array}$ & $\begin{array}{c}4 \\
\pm 0.5\end{array}$ & $\begin{array}{c}5 \\
\pm 0.5\end{array}$ & $\begin{array}{r}4 \\
\pm 1\end{array}$ & $\begin{array}{l}24^{\mathrm{a}, \mathrm{c}} \\
\pm 5\end{array}$ & $\begin{array}{l}16^{\mathrm{a}, \mathrm{c}} \\
\pm 2\end{array}$ \\
\hline $\begin{array}{l}\text { Cirrhotics } \\
\text { (SRIF + } \\
\text { glucagon) } \\
\text { D. }\end{array}$ & $\begin{array}{l}20 \\
\pm 3\end{array}$ & $\begin{array}{l}21 \\
\pm 3\end{array}$ & $\begin{array}{l}11 \\
\pm 2.5\end{array}$ & $\begin{array}{c}8 \\
\pm 1\end{array}$ & $\begin{array}{c}6 \\
\pm 1\end{array}$ & $\begin{array}{c}5 \\
\pm 1\end{array}$ & $\begin{array}{c}5 \\
\pm 1\end{array}$ & $\begin{array}{c}4 \\
\pm 1\end{array}$ & $\begin{array}{c}3 \\
\pm 0.5\end{array}$ & $\begin{array}{r}3.5 \\
\pm 0.5\end{array}$ & $\begin{array}{r}5 \\
\pm 1\end{array}$ & $\begin{array}{r}5 \\
\pm 1\end{array}$ & $\begin{array}{c}4 \\
\pm 0.5\end{array}$ & $\begin{array}{c}5 \\
\pm 0.4\end{array}$ & $\begin{array}{l}21^{\mathrm{b}, \mathrm{d}} \\
\pm 5\end{array}$ & $\begin{array}{l}22^{\mathrm{b}} \\
\pm 5\end{array}$ \\
\hline
\end{tabular}

decreased splanchnic glucose output $[3,5,6]$ mostly due to a decline in glycogenolysis [25].

Somatostatin-induced hypoglucagonaemia elicited the same effects in patients with cirrhosis, and presumably glucagon plays a similar role in fasting blood glucose homeostasis. In our studies, glycaemia fell by $37 \%$ in normals and by $41 \%$ in cirrhotics during the first 90 minutes of somatostatin infusion.

When somatostatin and saline infusion was continued beyond two hours in normal subjects, plasma glucose increased to hyperglycaemic values; when the infusion was interrupted, blood glucose returned to basal values. Somatostatin-induced hyperglycaemia is the result of decreased glucose utilization and return to normal [7] or even an increase [21] in hepatic glucose production. In cirrhotic patients we did not observe a rise in plasma glucose after the first 2 hours of somatostatin and saline infusion. This different plasma glucose pattern of cirrhotics, as compared to normal subjects, may be accounted for by the different concentration of metabolic substrates in liver tissue. In cirrhosis, glucose output from the liver is likely to depend on gluconeogenesis since the hepatic glycogen stores are virtually exhausted [20].

The addition of glucagon to somatostatin infusion in normal subjects enhanced the hyperglycaemic effect of prolonged somatostatin infusion producing a prompt twofold rise in plasma glucose due to increased glucose production [21]. In cirrhotics, the simultaneous infusion of somatostatin and glucagon 

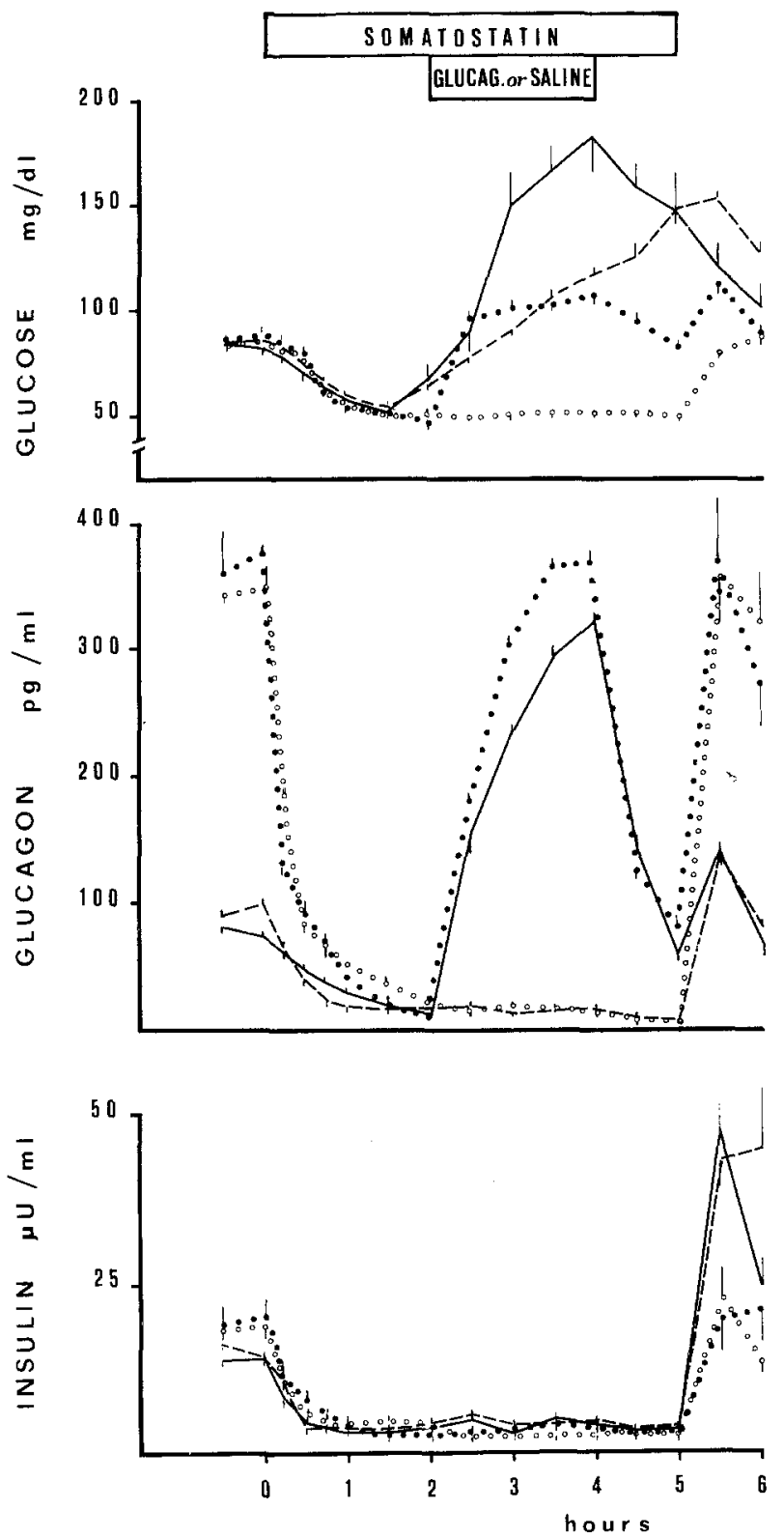

Fig. 1. Effects of somatostatin (SRIF) infusion $(500 \mu \mathrm{g} / \mathrm{h}) \mathrm{com}-$ bined with infusion of saline or glucagon $(3 \mathrm{ng} / \mathrm{kg} / \mathrm{min}$ ) on plasma glucose, insulin and glucagon in normal subjects and cirrhotic patients. --.-- SRIF + saline in normals; - SRIF + glucagon in normals; 000000 SRIF + saline in cirrhotics; $\bullet \bullet \bullet$ SRIF + glucagon in cirrhotics. Vertical lines represent SEM values

from the $2^{\text {nd }}$ to the $5^{\text {th }}$ hour brought about an increase in plasma glucose which lasted throughout the experiment but never reached the values observed in normal subjects. When the infusion was stopped, plasma glucose fell. Various factors may be thought to contribute to this response to glucagon in the cirrhotic patients: reduced liver glycogen content, porta-caval shunts which prevent the hormone from bringing its full action to bear on the cellular mass, or possible damage to liver glucagon receptors.

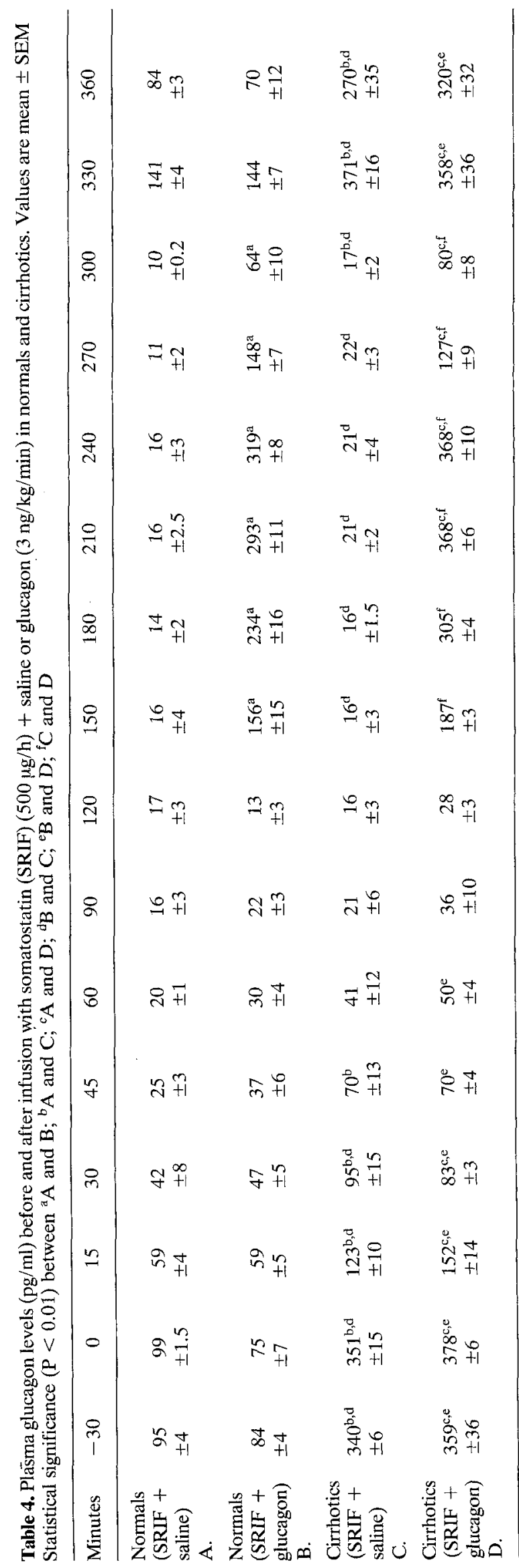


Our findings in cirrhotics submitted to prolonged somatostatin infusion show that when both insulin and glucagon were suppressed to unmeasurable concentrations, euglycaemia occurred only when the glucagon concentration was restored either exogenously or endogenously after 5 hours of somatostatin infusion.

Cirrhotic patients appear to lack the non-glucagon-dependent mechanisms of blood glucose control. In fact, the infusion of somatostatin alone did not bring about the rise in blood glucose observed in normal subjects, whereas the subsequent infusion of somatostatin and glucagon together had a hyperglycaemic action, albeit to a lesser extent than in normals. Thus, hyperglucagonaemia appears to be an active mechanism for the maintenance of blood glucose levels in cirrhosis.

Acknowledgements. Cyclic somatostatin was generously provided by Dr. E. Marchetti and Dr. F. De Tomasi (Instituto Farmacologico Serono, Rome, Italy).

This study was supported by a grant 78.02130 .04 from the C.N.R. (Consiglio Nazionale delle Ricerche), Rome, Italy.

\section{References}

1. Alberti K G MM, Christensen NJ, Christensen SE, Prange Hansen Aa, Iversen J, Lundbaek K, Seyer-Hansen K, Ørskov $\mathrm{H}$ (1973) Inhibition of insulin secretion by somatostatin. Lancet II: $1299-1301$

2. Alford F P, Bloom S R, Nabarro J D N, Hall R, Besser G M, Coy D H, Kastin A J, Schally A V (1974) Glucagon control of fasting glucose in man. Lancet II: 974-976

3. Altszuler N, Gottlieb B, Hampshire J (1976) Interaction of somatostatin, glucagon, and insulin on hepatic glucose output in the normal dog. Diabetes 25: 116-121

4. Berger D, Crowther R C, Floyd J C Jr, Pek S, Fayans S S (1978) Effect of age on fasting plasma levels of pancreatic hormones in man. J Clin Endocrinol Metab 47: 1183-1189

5. Bloomgarden Z T, Liljenquist J E, Cherrington A D, Rabinowitz D (1978) Persistent stimulatory effect of glucagon on glucose production despite downregulation. J Clin Endocrinol Metab 47: 1152-1155

6. Cherrington A D, Chiasson J L, Liljenquist J E, Jennings A S, Keller U, Lacy W W (1976) The role of insulin and glucagon in the regulation of basal glucose production in the postabsorptive dog. J Clin Invest 58: 1407-1418

7. Cherrington A D, Lacy W W, Chiasson J L (1978) Effect of glucagon on glucose production during insulin deficiency in the dog. J Clin Invest 62: 664-677

8. De Vane G W, Siler T M, Yen S S C (1974) Acute suppression of insulin and glucose levels by synthetic somatostatin in normal human subjects. J Clin Endocrinol Metab 38: 913-915

9. Gerich J E, Lorenzi M, Hane S, Gustafson G, Guillemin R, Forsham P H (1975) Evidence for a physiologic role of pancreatic glucagon in human glucose homeostasis: studies with somatostatin. Metabolism 24: 175-182

10. Gerich J E, Lorenzi M, Schneider V, Karam J H, Rivier J, Guillemin R, Forsham P H (1974) Effects of somatostatin on plasma glucose and glucagon levels in human diabetes mellitus. Pathophysiologic and therapeutic implications. N Engl J Med 291: 544-547
11. Greco A V, Fedeli G, Ghirlanda G, Manna R, Patrono C (1974) Behavior of pancreatic glucagon, insulin and HGH in liver cirrhosis, after arginine and i. v. glucose. Acta Diabetol Lat 11: 330-339

12. Hales CN, Randle P J (1963) Immunoassay of insulin with insulin-antibody precipitate. Biochem J 88: 137-146

13. Iversen J (1974) Inhibition of pancreatic glucagon release by somatostatin. Scand J Clin Lab Invest 33: 125-129

14. Liljenquist J E, Chiasson J L, Cherrington A D, Keller U, Jennings A S, Bomboy J D, Lacy W W (1976) An important role for glucagon in the regulation of glucose production in vivo. Metabolism 25 (Suppl 1): 1371-1373

15. Liljenquist J E, Mueller GL, Cherrington AD, Keller U, Chiasson J L, Perry J M, Lacy W W, Rabinowitz D (1977) Evidence for a important role of glucagon in the regulation of hepatic glucose production in normal man. J Clin Invest 59: 369-374

16. Marco J, Diego J, Villanueva ML, Diaz-Fierros M, Valverde I, Segovia J M (1973) Elevated plasma glucagon levels in cirrhosis of the liver. N Engl J Med 289: 1107-1111

17. Mortimer CH, Carr D, Lind T, Bloom S R, Mallinson CN, Schally A V, Tunbridge W M G, Yeomans L, Coy D H, Kastin A, Besser GM, Hall R (1974) Effects of growth-hormone release-inhibiting hormone on circulating glucagon, insulin and growth hormone in normal, diabetic, acromegalic, and hypopuitary patients. Lancet I: $697-701$

18. Perez G, Trimarco B, Ungaro B, Rengo F, Sacca' L (1978) Glucoregulatory response to insulin-induced hypoglycemia in Laennec's cirrhosis. J Clin Endocrinol Metab 46: 778-783

19. Sherwin R S, Fisher M, Bessoff J, Snyder N, Hendler R, Conn H O, Felig P (1978) Hyperglucagonemia in cirrhosis: altered secretion and sensitivity to glucagon. Gastroenterology 74 : $1224-1228$

20. Sherwin R, Joshi P, Hendler R, Felig P, Conn H O (1974) Hyperglucagonemia in Laennec's cirrhosis: the role of portalsystemic shunting. N Engl J Med 290: 239-242

21. Sherwin R S, Tamborlane W, Hendler R, Sacca' L, De Fronzo R A, Felig P (1977) Influence of glucagon replacement on the hyperglycemic and hyperketonemic response to prolonged somatostatin infusion in normal man. J Clin Endocrinol Metab 45: 1104-1107

22. Shurberg JL, Resnick R H, Koff R S, Ros E, Baum R A, Pallotta J A (1977) Serum lipids, insulin, and glucagon after portacaval shunt in cirrhosis. Gastroenterology 72: 301-304

23. Sperling M A, Graiwer L A, Leake R, Fisher D A (1976) Role of glucagon in perinatal glucose homeostasis. Metabolism 25 (Suppl 1): 1385-1386

24. Unger R H, Eisentraut A M, McCall M S, Madison L L (1962) Measurements of endogenous glucagon in plasma and the influence of blood glucose concentration upon its secretion. $J$ Clin Invest 41: 682-689

25. Wahren J, Efendic S, Luft R, Hagenfeldt L, Björkman O, Felig $P$ (1977) Influence of somatostatin on splanchnic glucose in postabsorptive and 60-hour fasted humans. J Clin Invest 59: 299-307

Received: August 9, 1978,

and in revised form: September 26, 1979

Dr. Aldo V. Greco

Istituto di Patologia Medica

Catholic University

Largo Gemelli 8

I-00168 Rome

Italy 